\title{
Assessment of Environmental and Human Health Risk for Contamination of Heavy Metal in Tilapia Fish Collected from Langat Basin, Malaysia
}

\author{
Lubna Alam 1, Mazlin Bin Mokhtar ${ }^{1}$, Md. Mahmudul Alam ${ }^{1}$, Md. Azizul Bari ${ }^{1}$, \\ Nicholas Kathijotes ${ }^{1}$, Goh Choo Ta ${ }^{1}$, and Lee Khai Ern ${ }^{1}$ \\ ${ }^{1}$ Institute for Environment and Development (LESTARI) \\ Universiti Kebangsaan Malaysia (UKM), Bangi, 43600, Selangor DE, Malaysia \\ ${ }^{2}$ Department of Civil Engineering \& Geomatics, Cyprus University of Technology \\ * Corresponding author, E-mail: lubna_762120@yahoo.com, Tel: +60389217656
}

\section{Citation Reference:}

Alam, L., Mokhtar, M., Alam, M.M., Bari, M. A., Nicholas, K., Ta, G.C., \& Khai, E.L. (2015). Assessment of Environmental and Human Health Risk for Contamination of Heavy Metal in Tilapia Fish Collected from Langat Basin, Malaysia. Asian Journal of Water, Environment and Pollution, 12(2), 21-30. [Online Link]

This is a pre-publication copy.

The published article is copyrighted by the publisher of the journal. 


\title{
Assessment of Environmental and Human Health Risk for Contamination of Heavy Metal in Tilapia Fish Collected from Langat Basin, Malaysia
}

\begin{abstract}
This investigation quantified spatial variability of heavy metals and followed methods of the U.S. Environmental Protection Agency (EPA) to estimate the hazard indices as well as cancer risks associated with consuming fish caught in the waters of the Langat river basin area, Malaysia. The calculation of metal pollution index (MPI) was carried out to classify the study area according to the level of contamination and the order of stations from highest to lowest MPI values was Langat river > Cempaka lake > Engineering pond > Pond B > Pond A > Jugra > Bandar. The level of exposure due to the consumption of each chemical in Tilapia fish tissue was estimated in an average daily dose equation. The calculated HI ranging from 0.24 to 1.88 indicated $71 \%$ stations were in the risk level. Potential carcinogenic risks associated with the ingestion of heavy metals in Tilapia fish were evaluated probabilistically by performing 10,000 trails for Monte Carlo simulation. Cancer risk calculations exceeding the U.S. EPA's acceptable risk level of 1 in $1,000,000$ (or $\left.10^{-6}\right)$ included $\mathrm{Ni}\left(7.3 \times 10^{-4}\right)$ and $\mathrm{Cd}$ $\left(2.1 \times 10^{-6}\right)$. However, the average carcinogenic risk $\left(2.4 \times 10^{-4}\right)$ exceeded the accepted risk level to a great extent. The recommended daily ingestion rate of Tilapia for Malaysian people inhabiting Langat river basin area was calculated considering $95^{\text {th }}$ percentile TR value of $10^{-6}$ as an acceptable risk where it is revealed that consumption of Tilapia should be reduced about $67 \%$ from the current level to have an acceptable risk of cancer.
\end{abstract}

Keywords: Risk, $H Q, H I, T R$, metal, Langat

\section{Introduction}

Heavy metals are considered as harmful because of their non-biodegradable nature, long biological half-lives and their potential to accumulate in different parts of the body (Núria et al., 2009). These metals can enter into the food web through direct consumption of water or organisms, or through uptake processes, and be potentially accumulated in edible fish (Paquin et al., 2003) which is a lean source of protein, vitamins, minerals and unsaturated essential fatty acids and consumption of fish have been encouraged by health professionals (Burger et al., 2007; Storelli, 2008). Consumption of these contaminated fishes showed potential risk for humans (USEPA., 2000; Storelli, 2008; Mallin et al., 2011; Mansilla-Rivera and RodríguezSierra, 2011). Similarly, it is reported that people can be exposed to toxic chemicals that accumulate in fish taken from contaminated waters that are consumed (Han et al., 1994; Svensson et al., 1995). The average $\mathrm{Cu}$ intake from contaminated green oysters for female individuals was 14 times more than that of international limits (Han et al., 1994). Studies revealed that people consuming large amounts of contaminated seafood may have elevated concentrations of pollutants in their tissues compared to the general population (Asplund et al., 1994; Dewailly et al., 1994 ). According to the findings of (Alam and Mohamed, 2011), fish consuming population inhabiting coal burning power plant area were exposed to a higher health risk. As a result, there is a growing concern that metals accumulated in fish muscle can represent a health risk, especially for populations with high fish consumption rates (Liao and Ling, 2003; Burger and Gochfeld, 2009; Díez et al., 2009).

The Langat River basin is a unique basin of Peninsular Malaysia since it passes through 3 distinct administrative regions of Federal Territory of Putrajaya and Cyberjaya, State of Selangor, and State of Negeri Sembilan. The entire basin is slightly less than 2,400 sq. $\mathrm{km}$. The total length of this river has been recorded at $200 \mathrm{~km}$ and ends its journey into 
the Straits of Malacca. The Langat River catchment achieved tremendous growth in the manufacturing sector, and has become the most industrialized area in Peninsular Malaysia. Therefore, Langat Basin water resource is under stress due to poor water quality and the continuous degradation of water quality of the Langat River is a concern for the public and policy makers. Langat River is also an important water resource to aquaculture projects located at the downstream areas. Malaysia is among the countries with the highest fish consumption in the world which relies on fish as a main source of animal protein. Aquaculture has grown rapidly around Langat river basin where a total of 177 ponds covering an area of 52.3 ha are located (Mokhtar et al., 2009). Even though Malaysia is a highly fish consuming country, unfortunately there are not enough studies conducted for the accepted level of fish consumption. The objective of this study is, therefore, to assess the environmental and human health risk due to the pollution of toxic heavy metals in the area of Langat river basin.

\section{Materials and Method}

\subsection{Data source}

Tilapia (Oreochromis spp) is a favored species of edible fish in Malaysia which is supplied from natural water bodies and cultured ponds. Moreover, as this fish species can survive in bad environmental conditions because of their resistance to disease (Zhou et al., 1998), it is considered to be an ideal species of organism for an assessment study on the effect of heavy metal contamination in aquaculture ponds (Mokhtar et al., 2009). Therefore, in this study, data of metal concentrations for Tilapia fish species, collected from different locations of Langat river basin, were obtained from the published result of (Taweel et al., 2011) and (Mokhtar et al., 2009) which are presented in Table 1.

\subsection{Calculation of Metal Pollution Index (MPI)}

Metal Pollution Index (MPI) is a procedure which reflects the status of heavy metal contamination in the environment. To compare the total metal content in the different sampling sites investigated in this study, the metal pollution index (MPI) was calculated according to (Usero et al., 1997) with the following formula:

$$
\text { MPI }=(C f 1 \times C f 2 \times \cdots \times C f n)^{1 / n} \text {. }
$$

Where $C f n$ is the concentration of the metal $n$ in the sample.

The MPI of the organisms was calculated by obtaining the n-root from the $\mathrm{C} f n$ that were obtained for all the metals.

\subsection{Health risk assessment procedure}

Human health risk assessment is the characterization of the potential adverse health effects of human exposures to environmental hazards (USEPA., 2012). This process employs the tools of science, engineering, and statistics to identify and measure a hazard, determine possible routes of exposure, and finally use that information to calculate a numerical value to represent the potential risk (Lushenko, 2010). A human health risk assessment involves four steps which are hazard identification, dose-response assessment, exposure assessment, and risk characterization. The concerning chemicals in a risk assessment fall into one of two categories, non-carcinogen or carcinogen, which determines the procedure for how the chemical is assessed and potential risks calculated. Non-carcinogenic chemicals are assumed to have a threshold; a dose below which no adverse health effects will be observed where an essential part of the dose-response portion of a risk assessment includes the use of a reference dose (RfD). On the other hand, carcinogens are assumed to have no effective threshold. This 
assumption implies that there is a risk of cancer developing with exposures at low doses and, therefore, there is no safe threshold for exposure to carcinogenic chemicals. Carcinogens are expressed by their Cancer Potency Factor (Lushenko, 2010).

Since the dietary intakes for humans are reported in terms of wet weight ingestion, thus, the wet weight conversion is applied to conduct the risk assessment and the calculated values are presented in Table 2. Equations for converting between dry and wet weight concentrations are obtained from (OhioEPA, 2008) and presented below:

Wet Weight $=($ Dry Weight $)(1-($ Percent moisture content/100) $) \ldots . .(2)$

In the present study, the non-carcinogenic human risk assessment was calculated according to (Onsanit et al., 2010) using the estimated daily intake (EDI) and reference dose (RfD) and estimated using the following equation:

$$
\mathrm{EDI}=\mathrm{M}_{\mathrm{C}} \times[\mathrm{IR} / \mathrm{BWa}]
$$

Where, $M_{C}=$ average trace element concentration in organism muscle $\left(\mu \mathrm{gg}^{-1}\right.$ wet weight), IR $=$ Fish consumption $\left(\right.$ gday $\left.^{-1}\right)$ per capita, and $\mathrm{BWa}=$ average body weight of target population. The Hazard quotient (HQ) is considered to be an estimate of the risk level (non-carcinogenic) due to pollutant exposure which is calculated from the following equation:

$$
\mathrm{HQ}=\mathrm{EDI} / \mathrm{RfD}
$$

A summation of the hazard quotients for all chemicals to which an individual is exposed was used to calculate the hazard index (USEPA, 2011).

$$
\mathrm{HI}=\mathrm{HQ}_{\mathrm{Pb}}+\mathrm{HQ}_{\mathrm{Cd}}+\mathrm{HQ}_{\mathrm{Ni}}+\mathrm{HQ}_{\mathrm{Cu}}+\mathrm{HQ}_{\mathrm{Cr}}+\mathrm{HQ}_{\mathrm{Zn}}
$$

Where, $\mathrm{HI}$ is the hazard index; $\mathrm{HQ}_{\mathrm{Pb}}$ is the target hazard quotient for $\mathrm{Pb}$ intake; $\mathrm{HQ}_{\mathrm{Cd}}$ is the target hazard quotient for $\mathrm{Cd}$ intake; $\mathrm{HQ}_{\mathrm{Ni}}$ is the target hazard quotient for $\mathrm{Ni}$ intake; $\mathrm{HQ}_{\mathrm{Cu}}$ is the target hazard quotient for $\mathrm{Cu}$ intake; $\mathrm{HQ}_{\mathrm{Cr}}$ is the target hazard quotient for Cr intake; and $\mathrm{HQ}_{\mathrm{Zn}}$ is the target hazard quotient for $\mathrm{Zn}$ intake.

Carcinogenic risk was evaluated by target cancer risk (TR). The method for estimating TR was provided in USEPA Region III Risk-Based Concentration Table (USEPA, 2011) and the model is shown as follows:

$\mathrm{TR}=\left(\mathrm{M}_{\mathrm{C}} \times \mathrm{IR} \times 10^{-3} \times\right.$ CPSo $\left.\times \mathrm{EF} \times \mathrm{ED}\right) /(\mathrm{BWa} \times \mathrm{ATc})$

Where, TR is the target cancer risk; $M_{C}$ is the metal concentration in fish $\left(\mu g g^{-1}\right)$; IR is the fish ingestion rate $\left(\mathrm{gday}^{-1}\right)$; CPSo is the carcinogenic potency slope, oral $\left(\mathrm{mg} / \mathrm{kg} \mathrm{bw}-\mathrm{day}^{-1}\right)$; and ATc is the averaging time, carcinogens (day years ${ }^{-1}$ ). The distribution of carcinogenic risk was estimated for $\mathrm{Ni}, \mathrm{Pb}$ and $\mathrm{Cd}$ as these are the elements for which an oral slope factor is derived. An averaging time of $365 \mathrm{~d} / \mathrm{yr}$ for 73 yrs (i.e., ATc $=26845.75 \mathrm{~d}$ ) was used to characterize lifetime exposure for cancer risk calculation (USEPA, 2011). The USEPA has concluded that a lifetime cancer risk of $10^{-6}$ ( 1 in a million) or less can generally be considered as acceptable, whereas a lifetime risk of $10^{-3}$ or greater is considered serious and requires attention. Risk level between $10^{-6}$ to $10^{-4}$ ( 1 in 10,000$)$ may also be up to standard but requires a case-specific judgment. The health protection standard of lifetime noncarcinogenic risk for HI is 1 (USEPA, 2011).

\section{Results and discussions}

\subsection{Environmental Risk Assessment}

Spatial analysis trends for Tilapia fish metals at seven sites around Langat river basin area were determined using the metal pollution index (MPI). The MPI values of six heavy metals in Tilapia fish of this study area are summarized in Figure 1. The concentrations of most of 
the metals in the Tilapia fish varied to a large extent depending on the locations of sampling sites and the highest MPI was recorded in the Langat River. This index provides a classification of the study area according to the level of contamination and the order of stations from highest to lowest MPI values was Langat river $>$ Cempaka lake>Engineering pond $>$ Pond $\mathrm{B}>$ Pond $\mathrm{A}>$ Jugra $>$ Bandar. The calculated values of present study are slightly higher than the values of Tilapia, collected from Ogun river catchment which ranged from 0.16 to 0.21 (Adeniyi et al., 2008). The MPI for two fish species (S. rivulatus and S. sargus) fluctuated between 0.9 and 1.8 in EI-Mex and Eastern Harbour (Khaled, 2004) which is in a good agreement with the present study. A much higher level of MPI was recorded for $P$. viridis collected from peninsular Malaysia (Amin et al., 2005) because the concentration of heavy metals in organisms exhibited the following decreasing order: cephalopod $>$ bivalve> crustacean>fish (Ahdy et al., 2007).

There is a long history of pollution in Langat River. In the year 2000, the Langat River was classified as averagely polluted (water quality index, WQI $=36-89$ ). Except for the upstream at the Hulu Langat area before $\mathrm{Sg}$. Lui where the river pollution is still relatively low and WQI is in class I, the downstream section of the Langat after the tributaries of Sg. Balak and Sg. Batang Benar is polluted with WQI reaching class III to IV (Khairuddin and Abd Malek, 2002). The Department of Environment (DOE) Malaysia has announced the Sungai Langat basin as a polluted river in 2006 due to rapid growth of industrialization in areas along the Sungai Langat basin (DOE, 2006; DOE., 2006). According to (The star, 2006), the drains from different kinds of premises lead to a larger drain and empties out into Sungai Langat. Moreover, the sewage from these premises is not channeled into any sewage treatment plant before the wastewater is released into Sungai Langat. In 2007, almost one million citizens in State of Selangor suffered because of the ammonia pollution in Sungai Langat and Sungai Selisik which are the main water supply intake points (Yusof, 2007). In 2009, Salak Tinggi Water Treatment Plant was shut down for a total of $2480 \mathrm{~h}$ because of poor water quality (PNSB., 2010). Lately in September 2010, the water treatment plant in Sungai Semenyih which is the main tributary of Sungai Langat basin was closed. The raw water supply from Sungai Kembong, was polluted due to the solid waste dumping in the nearby landfill area (Bernama, 2010 ). Moreover, it is recorded that sediments of the Juru and Langat rivers were contaminated by $\mathrm{Pb}$ and $\mathrm{Zn}$, while the Langat River was heavily contaminated by Cd. (Shazili et al. 2006). Besides that, a study conducted by (Mohamed et al., 2009) reported that agricultural and industrial activities were identified as the main pollution sources to groundwater and soil ecosystem in the Langat basin. The average concentration of $\mathrm{Pb}, \mathrm{Cd}, \mathrm{Fe}, \mathrm{Cu}$ in water samples obtained from the Langat river basin ranged from 0.074 to $0.100 \mathrm{mg} / \mathrm{l}, 0.0016$ to $0.032 \mathrm{mg} / \mathrm{l}, 0.82$ to $4.87 \mathrm{mg} / \mathrm{l}$, and 0.034 to $0.201 \mathrm{mg} / \mathrm{l}$, respectively (Yusuf and Nordin, 2003) that exceeded the Interim National Water Quality Standards (INWQS) by Ministry of Health Malaysia which are 0.05, 0.01, 1.0 and $0.20 \mathrm{mg} / \mathrm{l}$, respectively. Furthermore, it is recorded that the average level of $\mathrm{Ni}$ and $\mathrm{Zn}$ obtained from rivers in the Langat Basin ranged from 16.42 to $31.83 \mu \mathrm{g} / 1$ and 14.63 to $91.56 \mu \mathrm{g} / \mathrm{l}$, respectively (Yusuf and Nordin, 2003) which are quite high compared to the INWQS limit ( 0.05 and $5.0 \mathrm{mg} / \mathrm{l}$ respectively). This may indicate that the higher accumulation of heavy metal in Tilapia is because of the water pollution of Langat River. However, the $2^{\text {nd }}$ most polluted water body is Cempaka Lake, which is a man-made freshwater lake where the water supply comes from the rain water and mixes with sewage water from the adjacent restaurants that is drained finally through spillways to Langat River (Said et al., 2012). According to (Taweel et al., 2011), the concentration of heavy metals in fish collected from natural river and lakes can be higher than that collected from cultured ponds due to the fact that natural 
water sources are more exposed to contamination than controlled artificial ponds. Hence, the observed MPI values of natural water Tilapia fish are comparatively higher than cultured ponds.

\subsection{Health risk assessment}

\subsubsection{Non-carcinogenic risk assessment}

The heavy metal concentration for each chemical was used to estimate adverse noncarcinogenic health risk. Table 3 displays the calculated values of HQ and HI of Tilapia collected from different study locations. HQ larger than 1 implies the estimated exposure exceeded the USEPA reference dose for the contaminant of interest. Among all the analyzed heavy metals, Cr had the HQ value greater than 1 for Culture pond A, Culture pond B, Langat River, and Cempaka Lake. The HQ value for $\mathrm{Pb}$ reported in the current study ranged from 0.017 to 0.073 which were much lower than those measured in Tri states mining districts where the HQ ranged from 0.1 to 4.6 (Schmitt et al., 2006). A study done by (Mishra et al., 2007) in the Trans-Thane Creek area of Mumbai, measured the trace element in different types of marine organisms and reported the HQ values of $0.01\left(50^{\text {th }}\right.$ percentile $)$ and 0.005 $\left(95^{\text {th }}\right.$ percentile) in case of the ingestion of $\mathrm{Cd}$. The same study also revealed lower HQ values for $\mathrm{Cr}, \mathrm{Ni}, \mathrm{Zn}$ and $\mathrm{Cu}$ and suggested that consumption of fish were within the safe limit (Mishra et al., 2007). Similar to the findings, (Tu et al., 2008) worked on the concentration of $\mathrm{Cr}, \mathrm{Cu}, \mathrm{Zn}$, and $\mathrm{Cd}$, and measured $\mathrm{HQ}$ values of less than 1 which indicated that the local residents were not exposed to potential risk via consumption of shrimp. On the other hand, (Schmitt et al., 2006) reported a higher range of HQ values for $\mathrm{Cd}(0.1-0.5)$ and $\mathrm{Zn}(0.1-12.6)$ in carp fishes.

In the case of current study, although the observed values of $\mathrm{HQ}$ for $\mathrm{Pb}, \mathrm{Cd}, \mathrm{Ni}, \mathrm{Cu}$ and $\mathrm{Zn}$ were lower than the safe standard of 1 , but $\sum \mathrm{HQ}$ of these metals (HI) were higher than 1. The calculated HI ranged from 0.24 to 1.88 which indicates that $71 \%$ of stations are in the risk level while Bandar and Jugra were the only stations analyzed with HI values of less than 1. Samples of black-chin Tilapia, collected from Sukumo lagoon of Ghana, were analyzed for the concentration of heavy metals and the calculated values of $\mathrm{HI}$ indicated that the Tilapia did not pose any health risk to humans (Laar et al., 2011).

As contaminated fishes pose health risks, consumption advisories may recommend that people limit or avoid eating certain species of fish caught in certain places (USEPA, 2012). Therefore, every year since 1993, the EPA has made available to the public a compendium of information on locally issued fish advisories and safe eating guidelines. This information is provided to EPA by states, U.S. territories, Indian tribes, and local governments who issue fish consumption advisories and safe eating guidelines to inform people about the recommended level of consumption for fish caught in local waters. Similarly, OEHHA's fish advisories provide "safe eating guidelines" to help people choose the safest fish to eat and avoid fish species with high levels of chemicals in them which are based on sampling results for common fish species that people catch and eat from California's water bodies. Unfortunately, this information is not well developed in Malaysia. Therefore, the concept of OEHHA has been used in the present study to categorize the risk of fish consumption collected from different locations of study area and presented in Figure 2. In OEHHA's advisories, fish are divided into three categories based on their level of contamination (OEHHA, 2007). According to OEHHA, fish in the left panel are "green" and have a low level of contaminant. Fish in the middle panel are "yellow" and have a medium chemical level, whereas fish in the right panel are red and have a high chemical level. In the 
present study, the Tilapia fish collected from different locations are divided into 3 groups; A: Bandar and Jugra; B: Pond A and Pond B; and C: Langat River, Cempaka lake, and Engineering lake. Based on the values of the risk assessment, it is found that ingestion of Tilapia collected from Langat river, Cempaka lake, and Engineering lake (group C) may result in non-carcinogenic risk in consumers. Therefore, it is recommended that the fish consumption from these areas should be reduced.

\subsubsection{Carcinogenic risk assessment}

Of the six-targeted chemicals, carcinogenicity values were only reported for $\mathrm{Ni}, \mathrm{Pb}$, and $\mathrm{Cd}$ as no values of carcinogenic potency slope were available for the rest. Usually, the $5^{\text {th }}, 25^{\text {th }}$, $50^{\text {th }}, 75^{\text {th }}$ and $95^{\text {th }}$ percentiles of risk are considered to assess likelihoods of exceeding risk levels (Han et al., 2000; Liao and Ling, 2003; Jang et al., 2006). This study performed 10,000 trails for Monte Carlo simulation for risk assessment by using Excel 2010 for all area data. The simulation assumed normal distribution of data with mean (0.000739317) and standard deviation (0.000488501). The data are tested both with one tailed and two tailed. It is most logical that the health risk cannot be negative. Thus, the outcome of one tailed is more preferable than two tailed. The TRs for Ni calculated from $5^{\text {th }}, 25^{\text {th }}, 50^{\text {th }}, 75^{\text {th }}$ and $95^{\text {th }}$ percentiles are $7.76 \times 10^{-5}, 4.12 \times 10^{-4}, 7.21 \times 10^{-4}, 1.05 \times 10^{-3}$ and $1.5 \times 10^{-3}$, respectively (Figure $3 a)$. As these values are over one millionth, it is assumed that potential risk exists. The risk calculated for $\mathrm{Pb}$ was found to be low and the $50^{\text {th }}$ and $95^{\text {th }}$ percentile was $3.87 \times 10^{-7}$ and $7.99 \times 10^{-4}$ (Figure $3 \mathrm{~b}$ ). The calculated risk for $\mathrm{Cd}$ slightly exceeded the acceptable risk standard at $75^{\text {th }}$ and $95^{\text {th }}$ percentiles (Figure $3 \mathrm{c}$ ).

The average carcinogenic risk $\left(2.4 \times 10^{-4}\right)$ derived from the intake of metals greatly exceeded the generally accepted risk level of $10^{-6}$. This risk level is basically due to the dietary intake of Ni through Tilapia collected from natural sources. There is very limited research about the TRs values of $\mathrm{Ni}$. The average value of TR for $\mathrm{Ni}$ was $3.4 \times 10^{-4}$ for Tilapia collected from tropical wetland in India (Bhupander and Mukherjee, 2011). Comparing this result to the current study $\left(7.3 \times 10^{-4}\right)$, the cancer risk for tropical wet land fish is less than the present study. Similarly, TR calculated for Clam consumption in southern Taiwan ranged from $0.28 \times 10^{-6}$ to $4.52 \times 10^{-6}$ in the case of Arsenic which are also lower than the present study (Liu et al., 2007). The oyster samples from Taiwan showed TRs values of 12.6$38.2 \times 10^{-6}$ at $95^{\text {th }}$ percentile which are well above the present study (Liu et al., 2006). However, there is no published data available for the carcinogenicity of $\mathrm{Pb}$ and $\mathrm{Cd}$.

Considering $95^{\text {th }}$ percentile TR value of $10^{-6}$ as an acceptable risk, the associated recommended daily ingestion rate of Tilapia for Malaysians can be calculated by EQ (6). As $\mathrm{Pb}$ did not demonstrate any significant risk, only $\mathrm{Ni}$ and $\mathrm{Cd}$ were considered. Taking into account the mean concentration of $\mathrm{Ni}$ and $\mathrm{Cd}$, the safe daily intake was calculated as 40.25 g/day/person (Figure 4). Therefore, it can be assumed that Tilapia consumption should be reduced by about $67 \%$ from the current level to have an acceptable health cancer risk $\left(10^{-6}\right)$ from the exposure to $\mathrm{Ni}$ and $\mathrm{Cd}$ through the consumption of Tilapia collected from the Langat river area.

\section{Conclusion}

This work studied the environmental and human health risk due to pollution caused by toxic heavy metals at different places around the Langat River. Among all the studied locations, Tilapia of Langat River showed the highest MPI values and Bandar the lowest. It is assumed that the higher accumulation of heavy metals in Tilapia of Langat River is because of the long 
history of water pollution. Results from this study's human health risk assessment showed that there is an elevated risk, due to several chemicals, associated with the consumption of Tilapia fish at per capita ingestion rates of $45.1 \mathrm{kgyr}^{-1}$. The estimation of risk conducted in this study showed that adverse health effect may occur when consuming Tilapia fish mostly from the natural water bodies. Therefore, it is strongly recommended to take appropriate steps to identify ways to reduce the risk. However, the data collected and analyzed in this study epitomized the need to establish an ongoing monitoring program at Langat basin area. As no detailed data in different environmental aspects were available in the study area during this investigation, this study was not able to confirm the source of contamination for Tilapia. Therefore, more research should be performed in the Langat river area to establish precise fish consumption data and inspect contaminant concentrations in more fish species. The fish risk assessment of the present study was the first of its kind done in Malaysia and has provided a good platform to begin development of future research projects. That is why, it is recommended to continue this kind of research in order to create consumption advisory for Malaysian populace for any possible health risks.

\section{Acknowledgements}

Financial assistance provided by the research project "Dana Lonjakan Penerbitan (Ref. No. UKM-DLP-2011-083) is gratefully acknowledged. The authors wish to thank the Faculty of Science and Technology and Institute for Development and Environment (LESTARI), who have provided the secondary data and valuable advice.

\section{References}

Adeniyi, A., Yusuf, K., Okedeyi, O., 2008. Assessment of the exposure of two fish species to metals pollution in the Ogun river catchments, Ketu, Lagos, Nigeria. Environmental Monitoring and Assessment 137, 451-458.

Ahdy, H.H.H., Abdallah, A.M.A., Tayel, F.T., 2007. Assessment of heavy metals and nonessential content of some edible and soft tissue. Egyptian Journal of Aquatic Research 33, 85-97.

Alam, L., Mohamed, C.A.R., 2011. Natural radionuclide of $\mathrm{Po}^{210}$ in the edible seafood affected by coal-fired power plant industry in Kapar coastal area of Malaysia. Environmental Health 10, 1-10.

Amin, B., Ismail, A., M.S, K., Arshad, A., Yap, C.K., 2005. Heavy Metals (Cd, Cu, Ph and $\mathrm{Zn})$ Concentrations in Telescopium telescopium from Dumai Coastal Waters, Indonesia. Pertanika Journal of Tropical Agricultural Science 28, 33 - 39.

Asplund, L., Svensson, B., Nilsson, A., Eriksson, U., Jansson, B., Jensen, S., Wideqvist, U., Skerfving, S., 1994. Polychlorinated biphenyls, 1,1,1-trichloro-2,2-bis(pchlorophenyl)ethane (p,p'-DDT) and 1,1-dichloro-2,2-bis(p-chlorophenyl)-ethylene ( $\left.p, p^{\prime}-\mathrm{DDE}\right)$ in human plasma related to fish consumption. Archives of Environmental Health 49, 477-486.

Bernama, 2010 Syabas Tutup Sementara Loji Semenyih Berikutan Pencemaran.

Bhupander, K., Mukherjee, D.P., 2011. Assessment of Human Health Risk for Arsenic, Copper, Nickel, Mercury and Zinc in Fish Collected from Tropical Wetlands in India. Advances in Life Science and Technology 2, 13-25.

Burger, J., Gochfeld, M., 2009. Perceptions of the risks and benefits of fish consumption: Individual choices to reduce risk and increase health benefits. Environmental Research 109, 343-349.

Burger, J., Gochfeld, M., Shukla, T., Jeitner, C., Burke, S., Donio, M., Shukla, S., Snigaroff, R., Snigaroff, D., Stamm, T., Volz, C., 2007. Heavy metals in Pacific cod (Gadus 
macrocephalus) from the Aleutians: location, age, size, and risk. Journal of Toxicology and Environmental Health, Part A 70 1897-1911.

Dewailly, E., Ryan, J.J., Laliberté, C., Bruneau, S., Weber, J.P., Gingras, S., Carrier, G., 1994 Exposure of remote maritime populations to coplanar PCBs. 102, 205-209.

Díez, S., Delgado, S., Aguilera, I., Astray, J., Pérez-Gómez, B., Torrent, M., Sunyer, J., Bayona, J., 2009. Prenatal and early childhood exposure to mercury and methylmercury in Spain, a high-fish-consumer country. Arch Environ Contam Toxicol 56, 615-622.

DOE, 2006. Malaysia environmental quality report 2006 in Impak, Kuala Lumpur. in: Environment, M.o.S.T.a. (Ed.), pp. 1-16.

DOE., 2006. Malaysia environmental quality report 2006 in Impak, Kuala Lumpur. in: Environment, M.o.S.T.a. (Ed.), pp. 1-16.

Han, B.-C., Jeng, W.-L., Hung, T.-C., Jeng, M.-S., 1994. Copper intake and health threat by consuming seafood from copper-contaminated coastal environments in taiwan. Environmental Toxicology and Chemistry 13, 775-780.

Han, B.-C., Jeng, W.-L., Hung, T.-C., Ling, Y.-C., Shieh, M.-J., Chien, L.-C., 2000. Estimation of metal and organochlorine pesticide exposures and potential health threat by consumption of oysters in Taiwan. Environmental Pollution 109, 147-156.

Jang, C.S., Liu, C.W., Lin, K.H., Huang, F.M., Wang, S.W., 2006. Spatial analysis of potential carcinogenic risks associated with ingesting arsenic in aquacultural tilapia (Oreochromis mossambicus) in blackfoot disease hyperendemic areas. Environmental Science \& Technology 40, 1707-1713.

Khairuddin, M.I., Abd Malek, A., 2002. Program pencegahan pencemaran dan peningkatan kualiti air sungai Langat. Proceeding Simposium Penyelidikan Lembangan Langat 2001. in: Mazlin, M., Shaharuddin, I., Ahmad Fariz, M.A., Abdul Hadi, H.S., Sarah, A.A.G.A. (Eds.). Lestari, UKM, Bangi, pp. 183-189.

Khaled, A., 2004. Seasonal concentrations of some heavy metals in muscle tissues of Siganus rivulatus and Sargus sargus fish from El-mex bay and eastern harbour, Alexandria, Egypt. Egyptian Journal of Aquatic Biology and Fisheries 8, 65-81.

Laar, C., Fianko, J.R., Akiti, T.T., Osae, S., Brimah, A.K., 2011. Determination of heavy metals in the black-chin tilapia from the Sakumo Lagoon, Ghana. Research Journal of Environmental and Earth Sciences 3, 8-13.

Liao, C.M., Ling, M.P., 2003. Assessment of human health risks for arsenic bioaccumulation in tilapia (Oreochromis mossambicus) and large-scale mullet (Liza macrolepis) from blackfoot disease area in Taiwan. Arch Environ Contam Toxicol 45, 264-272.

Liu, C.W., Liang, C.P., Huang, F.M., Hsueh, Y.M., 2006. Assessing the human health risks from exposure of inorganic arsenic through oyster (Crassostrea gigas) consumption in Taiwan. Science of The Total Environment 361, 57-66.

Liu, C.W., Liang, C.P., Lin, K.H., Jang, C.S., Wang, S.W., Huang, Y.K., Hsueh, Y.M., 2007. Bioaccumulation of arsenic compounds in aquacultural clams (Meretrix lusoria) and assessment of potential carcinogenic risks to human health by ingestion. Chemosphere 69, 128-134.

Lushenko, M.A., 2010. A risk assessment for ingestion of toxic chemicals in fish from Imperial beach, California. Public Health. San Diego State University.

Mallin, M., McIver, M., Fulton, M., Wirth, E., 2011. Elevated Levels of Metals and Organic Pollutants in Fish and Clams in the Cape Fear River Watershed. Arch Environ Contam Toxicol 61, 461-471.

Mansilla-Rivera, I., Rodríguez-Sierra, C., 2011. Metal Levels in Fish Captured in Puerto Rico and Estimation of Risk from Fish Consumption. Arch Environ Contam Toxicol 60, $132-144$. 
Mishra, S., Bhalke, S., Saradhi, I.V., Suseela, B., Tripathi, R.M., Pandit, G.G., Puranik, V.D., 2007. Trace metals and organometals in selected marine species and preliminary risk assessment to human beings in Thane Creek area, Mumbai. Chemosphere 69, 972-978.

Mohamed, A.F., Yaacob, W.Z.W., Taha, M.R., Samsudin, A.R., 2009. Groundwater and Soil Vulnerability in the Langat Basin Malaysia. European Journal of Scientific Research 27, 628-635.

Mokhtar, M.B., Aris, A.Z., Munusamy, V., Praveena, S.M., 2009. Assessment Level of Heavy Metals in Penaeus Monodon and Oreochromis Spp in Selected Aquaculture Ponds of High Densities Development Area. European Journal of Scientific Research 30, 348-360.

Núria, F.H., Martí, N., Pablo, D.L.I., Diogène., Jorge., José L. D., 2009. Risk assessment of trace elements from consuming local seafood by the population living in the Ebro river basin in Catalonia, Spain. ICMSS09 - Nantes.

OEHHA, 2007. Fish. California Environmental Protection Agency California.

OhioEPA, 2008. Ecological Risk Assessment Guidance Document. Division of Environmental Response and Revitalization, Lazarus Government Center, 50 West Town St., Suite 700, Columbus.

Onsanit, S., Ke, C., Wang, X., Wang, K.-J., Wang, W.-X., 2010. Trace elements in two marine fish cultured in fish cages in Fujian province, China. Environmental Pollution $158,1334-1342$.

Paquin, R.R., Farley, K., Santore, R.C., Kavvadas, C.D., Mooney, K.G., Winfield, R.P., Wu, K.B., Di Toro, D.M., 2003. Metals in aquatic systems: a review of exposure, bioaccumulation, and toxicity models. Society of Environmental Toxicology and Chemistry (SETAC). Pensacola.

PNSB., 2010. 2009 annual report. Kuala Lumpur, pp. 125-129.

Said, K.S., Shuhaimi, M., Kutty, A., 2012. The water quality and metal concentrations of Cempaka Lake, Selangor, Malaysia. in: Brebbia, C.A., Zubir, S.S. (Eds.). Management of natural resources, sustainable development and ecological hazards. WIT Press, pp. 47-52.

Schmitt, C., Brumbaugh, W., Linder, G., Hinck, J.E., 2006. A Screening-Level Assessment of Lead, Cadmium, and Zinc in Fish and Crayfish from Northeastern Oklahoma, USA. Environmental Geochemistry and Health 28, 445-471.

Storelli, M.M., 2008. Potential human health risks from metals $(\mathrm{Hg}, \mathrm{Cd}$, and $\mathrm{Pb}$ ) and polychlorinated biphenyls (PCBs) via seafood consumption: Estimation of target hazard quotients (THQs) and toxic equivalents (TEQs). Food and Chemical Toxicology 46, 2782-2788.

Svensson, B.G., Nilsson, A., Jonsson, E., Schütz, A., Akesson, B., Hagmar, L., 1995. Fish consumption and exposure to persistent organochlorine compounds, mercury, selenium and methylamines among Swedish fishermen. Scandinavian Journal of Work, Environment \& Health 21, 96-105.

Taweel, A., M.S., O., Ahmad, A.K., 2011. Heavy metals concentration in different organs of tilapia fish (Oreochromis niloticus) from selected areas of Bangi, Selangor, Malaysia. African Journal of Biotechnology 10, 11562-11566.

The star, 2006. Environment

Tu, N.P.C., Ha, N.N., Ikemoto, T., Tuyen, B.C., Tanabe, S., Takeuchi, I., 2008. Regional variations in trace element concentrations in tissues of black tiger shrimp Penaeus monodon (Decapoda: Penaeidae) from South Vietnam. Marine Pollution Bulletin 57, 858-866.

USEPA, 2011. USEPA Regional Screening Level (RSL) Summary Table. Washington, DC. 
USEPA, 2012. Fish Consumption Advisories. Washington, D.C.

USEPA., 2000. Guidance for Assessing Chemical Contaminant Data for Use in Fish Advisories: Volume 1. Fish Sampling and Analysis 3rd Edition. DC EPA 823-B-00007, Office of Science and Technology of Water, Washington, pp. 1-200.

USEPA., 2012. Waste and Cleanup Risk Assessment.

Usero, J., González-Regalado, E., Gracia, I., 1997. Trace metals in the bivalve molluscs Ruditapes decussatus and Ruditapes philippinarum from the atlantic coast of Southern Spain. Environment International 23, 291-298.

Yusof, M.F., 2007. The water crisis in Selangor? - A million population will be affected two ammonia contaminated river. Utusan.

Yusuf, M.A., Nordin, M., 2003. River water quality assessment and ecosystem health: Langat River Basin, Selangor, Malaysia. in: Rapport, D.J., Lesley, W.L., Rolston, D.E., Nielson, N.O., Quelset, C.O., Damania, A.D. (Eds.). Managing for healthy ecosystems. Lewis/CRC Press, Boca Raton, Flourida.

Zhou, H.Y., Cheung, R.Y.H., Chan, K.M., Wong, M.H., 1998. Metal concentrations in sediments and tilapia collected from inland waters of Hong Kong. Water Research 32, 3331-3340. 
Table 1: Mean concentration of heavy metals in Tilapia fish (Oreochromis spp) in different location of Langat river basin

\begin{tabular}{ccccccc}
\hline \multirow{2}{*}{ Location } & \multicolumn{5}{c}{ Heavy metal concentration $(\mu \mathrm{g} / \mathrm{g}$ dry weight $)$} \\
\cline { 2 - 7 } & $\mathrm{Pb}$ & $\mathrm{Cd}$ & $\mathrm{Ni}$ & $\mathrm{Cu}$ & $\mathrm{Cr}$ & $\mathrm{Zn}$ \\
\hline Bandar & $0.42 \pm 0.09$ & $0.02 \pm 0.00$ & $0.05 \pm 0.01$ & $0.31 \pm 0.04$ & $0.71 \pm 0.08$ & $1.92 \pm 0.06$ \\
Jugra & $0.40 \pm 0.02$ & $0.01 \pm 0.00$ & $0.11 \pm 0.02$ & $0.32 \pm 0.02$ & $0.81 \pm 0.07$ & $2.32 \pm 0.07$ \\
Pond A & $0.11 \pm 0.01$ & $0.01 \pm 0.0$ & $2.8 \pm 0.25$ & $0.313 \pm 0.76$ & $6.21 \pm 0.6$ & $31 \pm 2.8$ \\
Pond B & $0.10 \pm 0.01$ & $0.01 \pm 0.0$ & $2.7 \pm 0.17$ & $2.33 \pm 0.16$ & $6.1 \pm 0.29$ & $29 \pm 1.6$ \\
Langat River & $0.18 \pm 0.04$ & $0.02 \pm 0.0$ & $3 \pm 0.22$ & $5.47 \pm 0.49$ & $5.92 \pm 0.32$ & $33 \pm 5.3$ \\
Cempaka lake & $0.15 \pm 0.01$ & $0.03 \pm 0.0$ & $3.2 \pm 0.33$ & $3.4 \pm 0.74$ & $6 \pm 0.15$ & $37 \pm 0.06$ \\
Engineering lake & $0.14 \pm 0.05$ & $0.03 \pm 0.0$ & $3 \pm 0.43$ & $2.36 \pm 0.4$ & $5.7 \pm 0.22$ & $45 \pm 0.8$ \\
\hline
\end{tabular}

Source: Taweel et. al. [18] and Mokhtar et. al.[16].

Table 2: Concentration of Heavy metal $(\mu \mathrm{g} / \mathrm{g}$ WW) in analyzed Tilapia fish

\begin{tabular}{ccccccc}
\hline \multirow{2}{*}{ Location } & \multicolumn{6}{c}{ Heavy metal concentration $(\mu \mathrm{g} / \mathrm{g}$ WW $)$} \\
\cline { 2 - 7 } & $\mathrm{Pb}$ & $\mathrm{Cd}$ & $\mathrm{Ni}$ & $\mathrm{Cu}$ & $\mathrm{Cr}$ & $\mathrm{Zn}$ \\
\hline Bandar & 0.10 & 0.00 & 0.01 & 0.08 & 0.18 & 0.48 \\
Jugra & 0.10 & 0.00 & 0.03 & 0.08 & 0.20 & 0.59 \\
Pond A & 0.03 & 0.00 & 0.70 & 0.08 & 1.55 & 7.75 \\
Pond B & 0.03 & 0.00 & 0.68 & 0.58 & 1.53 & 7.25 \\
Langat River & 0.05 & 0.01 & 0.75 & 1.37 & 1.48 & 8.25 \\
Cempaka lake & 0.04 & 0.01 & 0.80 & 0.85 & 1.50 & 9.25 \\
Engineering & & & & & & \\
lake & 0.04 & 0.01 & 0.75 & 0.59 & 1.43 & 11.25 \\
\hline
\end{tabular}


Table 3 Calculated values of HQ and HI in Tilapia fish

\begin{tabular}{|c|c|c|c|c|c|c|c|}
\hline \multirow{2}{*}{ Locations } & \multicolumn{6}{|c|}{ HQ } & \multirow{2}{*}{$\mathrm{HI}$} \\
\hline & $\mathrm{Pb}$ & $\mathrm{Cd}$ & $\mathrm{Ni}$ & $\mathrm{Cu}$ & $\mathrm{Cr}$ & $\mathrm{Zn}$ & \\
\hline Bandar & 0.073 & 0.008 & 0.001 & 0.004 & 0.124 & 0.033 & 0.243 \\
\hline Jugra & 0.069 & 0.003 & 0.001 & 0.004 & 0.142 & 0.041 & 0.261 \\
\hline Pond A & 0.019 & 0.005 & 0.029 & 0.004 & 1.084 & 0.541 & 1.683 \\
\hline Pond B & 0.017 & 0.005 & 0.028 & 0.030 & 1.065 & 0.506 & 1.652 \\
\hline Langat River & 0.031 & 0.010 & 0.031 & 0.072 & 1.033 & 0.576 & 1.754 \\
\hline Cempaka lake & 0.026 & 0.016 & 0.034 & 0.045 & 1.047 & 0.646 & 1.813 \\
\hline $\begin{array}{l}\text { Engineering } \\
\text { lake }\end{array}$ & 0.024 & 0.016 & 0.031 & 0.031 & 0.995 & 0.785 & 1.883 \\
\hline
\end{tabular}

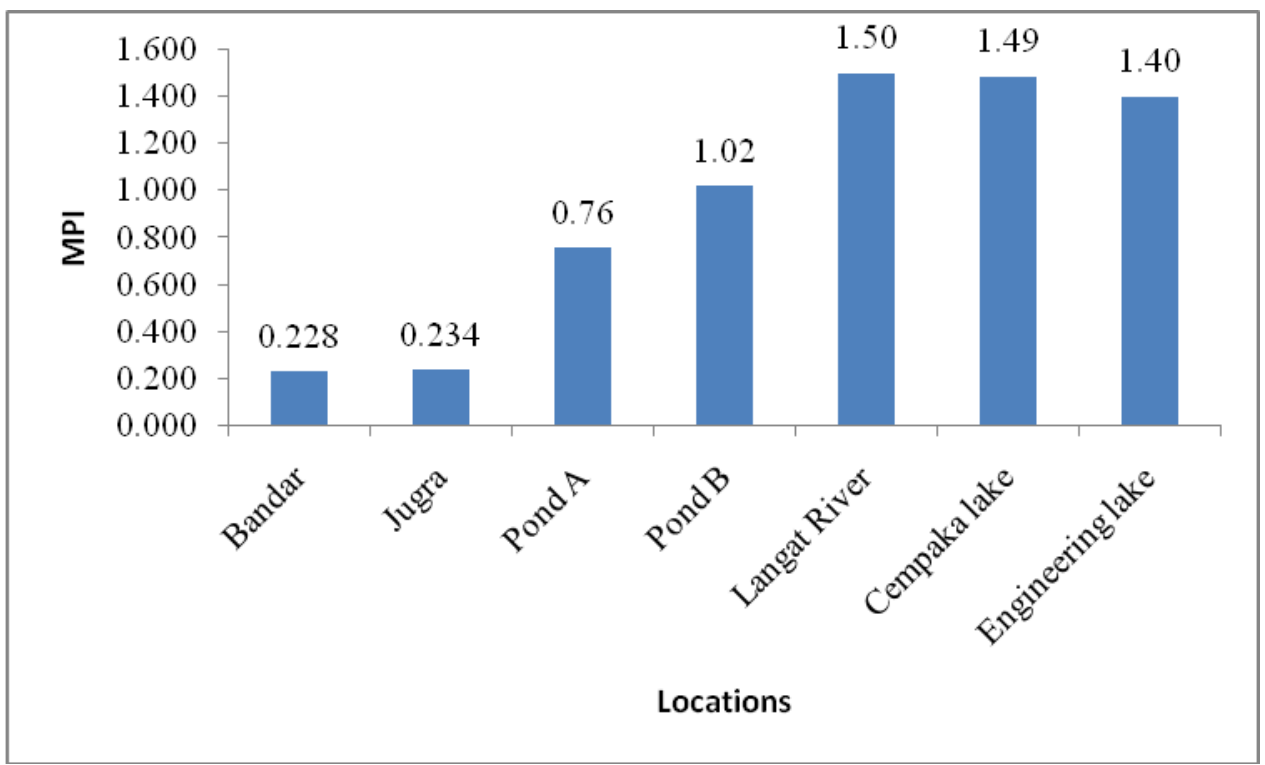

Figure 1: Calculated values of MPI in different locations of Langat Basin area 


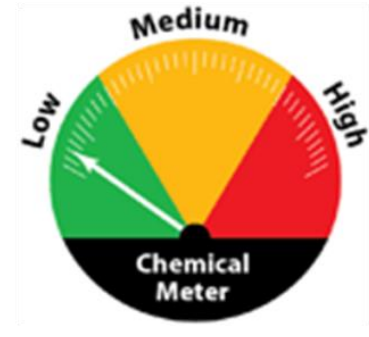

A

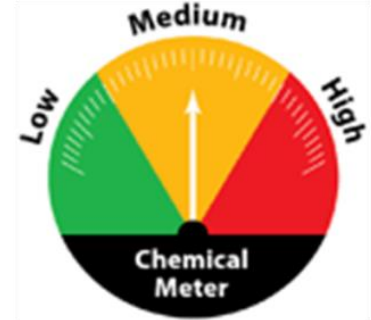

B

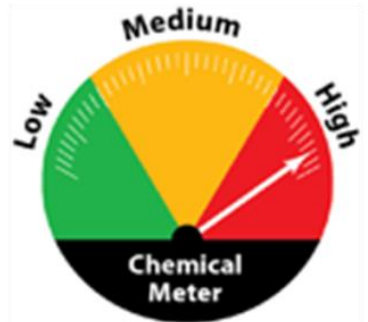

C

$\mathrm{A}=$ Bandar and Jugra

$\mathrm{B}=$ Pond $\mathrm{A}$ and Pond $\mathrm{B}$

$\mathrm{C}=$ Langat River, Cempaka lake and Engineering lake

Figure 2: Fish consumption advisory diagram for Langat basin area

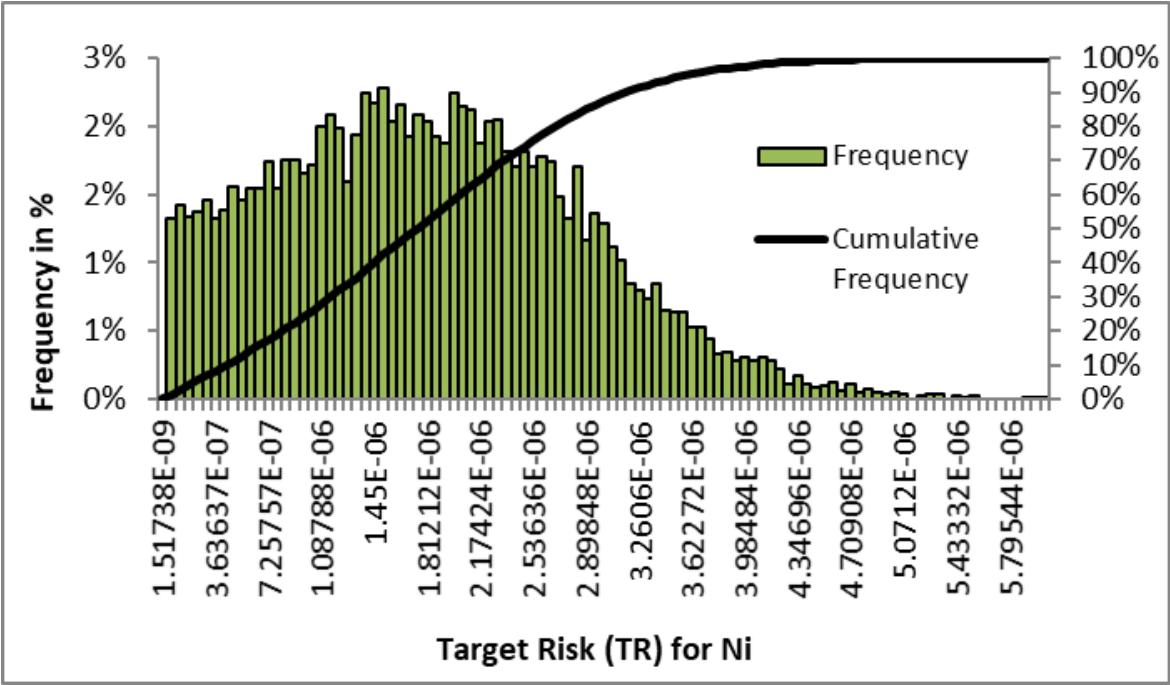

(a)

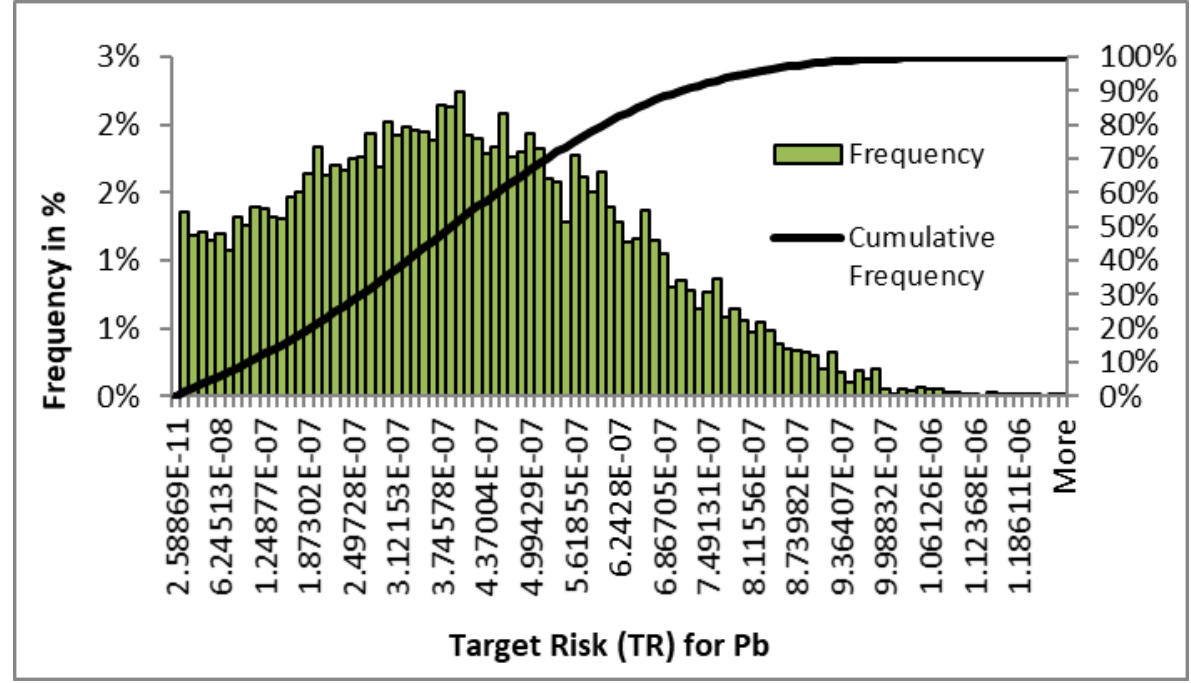

(b) 


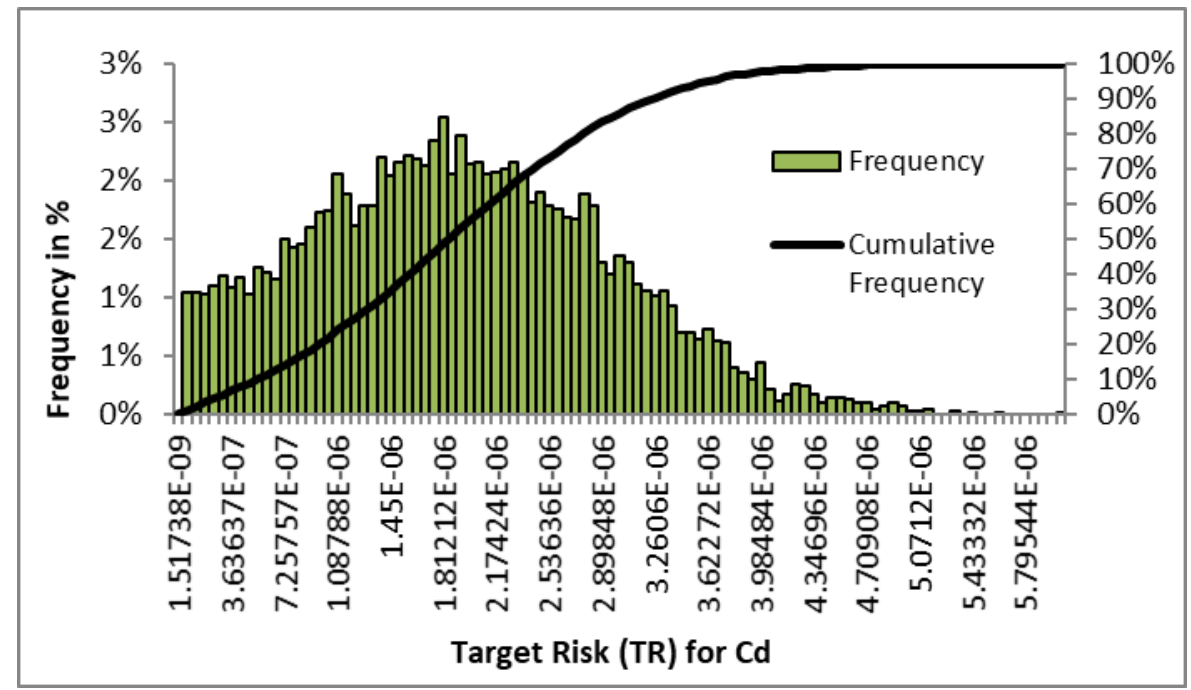

(c)

Figure 3: The Frequency Distributions of the Simulation (One Tailed) for $\mathrm{Ni}, \mathrm{Pb}$ and $\mathrm{Cd}$.

\begin{tabular}{|c|c|c|c|}
\hline \multicolumn{3}{|l|}{140} & $3.00 \mathrm{E}-04$ \\
\hline & Current & & \\
\hline 120 & Counsumption & current Risk & $2.50 \mathrm{E}-04$ \\
\hline & (g/day/person) & Level, 2.47E-04 & \\
\hline 100 & Level, 123.56 & & $2.00 \mathrm{E}-04$ \\
\hline 80 & & & \\
\hline 60 & & & $1.50 \mathrm{E}-04$ \\
\hline & Accepted & & $1.00 \mathrm{E}-04$ \\
\hline 40 & Counsumption & & \\
\hline 20 & (g/day/person) & Accepted Risk & 5.00E-05 \\
\hline & Level, 40.25 & Level, 1.00E-06 & \\
\hline
\end{tabular}

Figure 4: Gap between accepted and current level for fish consumption and health risk of Malaysian people

Supplementary 1. Summary statistics of input parameters in the health risk estimation

\begin{tabular}{cccc}
\hline Symbol & Description & Unit & Value \\
\hline MC & Average trace element & $\mu$ gg-1 wet & Presented in Table 2 \\
& concentration in organism & weight & \\
muscle & &
\end{tabular}


IR Fish consumption per capita gday-1 Per capita fish consumption for Malaysia was 45.1 kgyr-1= 123.56 gday-1

(Statistic of Agro Food 2010).

EF Exposure frequency days year-1

ED Exposure duration years

350 (Liu et al. 2007)

RfD Reference dose $\quad \mu g g-1$ day-1 $\mathrm{Pb}=0.003$ (EC 2004; Tu et al. 2008)),

$$
\begin{gathered}
\mathrm{Cd}=0.001, \mathrm{Ni}=0.05, \mathrm{Cu}=0.04, \mathrm{Cr}= \\
0.003, \mathrm{Zn}=0.03(\underline{\text { USEPA 2011 }})
\end{gathered}
$$

BWa The average body weight of $\mathrm{kg} \quad$ The average body weight of Malaysian target population $\quad$ population was $59.23 \mathrm{~kg}$ ( Lim et al.

$\underline{2000)}$.

ATc Averaging time carcinogens days 26845.75

CPSo Carcinogenic potency slope, $\mu \mathrm{g} \mathrm{g}-1$ day$\mathrm{Ni}=1.7$ (USEPA 2011), oral $1 \quad \mathrm{~Pb}=0.009, \mathrm{Cd}=0.6(\underline{\text { OEHHA 2011 }})$ 